\title{
Belgeo
}

Revue belge de géographie

1-2-3-4 | 2000

Special issue: 29th International Geographical

Congress

\section{The Euroregion, nodal centre of the Western European HST network}

Yves Rouyet

\section{(2) OpenEdition}

Journals

Electronic version

URL: http://journals.openedition.org/belgeo/14087

DOI: $10.4000 /$ belgeo. 14087

ISSN: 2294-9135

Publisher:

National Committee of Geography of Belgium, Société Royale Belge de Géographie

\section{Printed version}

Date of publication: 30 December 2000

Number of pages: 163-164

ISSN: 1377-2368

\section{Electronic reference}

Yves Rouyet, "The Euroregion, nodal centre of the Western European HST network », Belgeo [Online], 1-2-3-4 | 2000, Online since 13 July 2015, connection on 19 April 2019. URL : http:// journals.openedition.org/belgeo/14087; DOI : 10.4000/belgeo.14087

This text was automatically generated on 19 April 2019

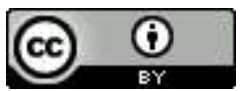

Belgeo est mis à disposition selon les termes de la licence Creative Commons Attribution 4.0 International. 


\title{
The Euroregion, nodal centre of the Western European HST network
}

\author{
Yves Rouyet
}

1 The analysis of the HST supply in Europe reveals the strategic position held by the Euroregion within the structuring of the European high speed railway network as reflected on the map on the next page.

The HST supply can be appraised from three perspectives.

The first consists in identifying the areas crossed by railway lines with HST operation. These lines can be classified according to their adaptation to more or less high speeds. The high speed lines are specifically designed for HSTs, as is the case of the 3-branch cross connecting Brussels, Paris and Ashford via Lille. In most cases such lines form the framework of the whole network, on which pre-existing lines are grafted, accessible to high speed trains but only at ordinary speeds, as in the Walloon axis, in Flanders and in a range of towns of the Nord-Pas-de-Calais. Some of these lines have been adapted to higher speeds, though never reaching $300 \mathrm{~km} / \mathrm{h}$. This will be the case of the BrusselsAntwerp connection.

4 The second perspective concerns the local servicing. A region crossed by an HST line will obviously only benefit from an HST effect if the trains stop there. It is therefore necessary to take into account the number of daily stops. The major difficulty in analysing the HST network lies in its permanent changing. On one side the infrastructure works are going on everywhere in Europe but, on the other side, the railway companies are regularly modifying their supply depending either on their schedule (the timetables vary with the weekdays or the touristic seasons), or on major strategic reorientation schemes, such as the servicing of an international airport. This is the reason why we have retained as 'normal' supply the number of high speed trains stopping on a Wednesday, in order to avoid the special timetables of Monday and Friday, which are dependent on the weekly commuting and the weekend departures. We have based our analysis on the 1999-2000 winter timetables. 
Here again, the map shows the significance of the Euroregion through its high density in HST stations and the number of HST stops, especially in the Nord-Pas-de-Calais.

As to the third perspective, it concerns the very nature of the network manager. A closer look allows to find out that the European HS network is, in reality, made of a series of national networks, possibly superposed on their margins, and of 2 networks with a European calling. The latter two, Thalys and Eurostar, enjoy a real international status since they were issued by the railway companies of the different countries they serve. Considering those networks, the Euroregion (and more particularly Lille and Brussels) plays the part of a hub between the European economic poles such as Paris, London, Randstad Holland and the Ruhr. Moreover, the towns of the Nord-Pas-de-Calais as well as Brussels are also served by the HS trains of the French network. In addition, Brussels will soon be connected to the ICE network.

In our analysis we have taken the following HSTs into account: TGV (France, Switzerland, Belgium), ICE (Germany, Switzerland, Austria), Cisalpino (Italy and Switzerland), Eurostar Italia (Italy), Alta Velocidad Española, Euromed, Alaris and Talgo 200 (Spain exclusively), Thalys (France, Belgium, Germany, The Netherlands) and Eurostar (France, Belgium, Britain).

The map also roughly shows the pattern of the population density, reflecting the size of the demand.

Figure 1. European HST network supply (winter 99-00).

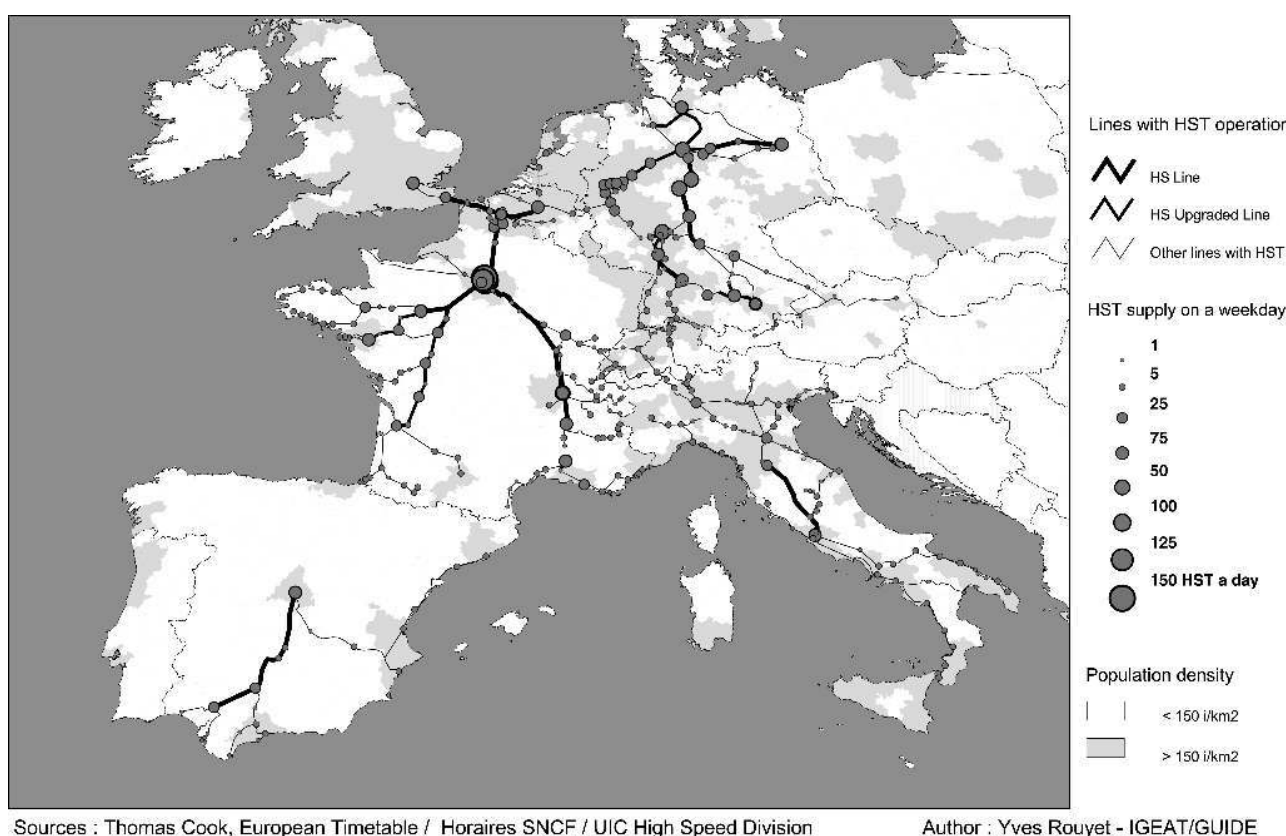




\section{AUTHOR}

\section{YVES ROUYET}

Université Libre de Bruxelles 